\title{
Biological Effectiveness of Plant Polyphenols under Greenhouse Conditions, Against Wilt and Root Rot Complex of Chickpea (Cicer arietinum L.)
}

Canadian Journal of Agriculture and Crops

Vol. 6, No. 1, 10-21, 2021

e-ISSN: 2518-6655

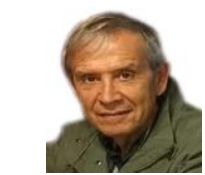

\& Corresponding Author

\author{
(iD) Ivón Alejandra ROSAS-JÁUREGUI ${ }^{1}$ \\ Guillermo FUENTES-DÁVILA ${ }^{2}$ \\ Francisco Daniel HERNÁNDEZ-CASTILLO ${ }^{3}$ \\ José Luis FÉLIX-FUENTES ${ }^{4}$ \\ iD Alma Angélica ORTIZ-AVALOS ${ }^{5}$ \\ D Juan Manuel CORTÉS-JIMÉNEZ ${ }^{6}$ \\ iD Diana COTA-UNGSON ${ }^{\text {? }}$
}

\author{
${ }^{1,3,7}$ Universidad Autónoma Agraria Antonio Narro Calzada Antonio Narro, Buenavista, Saltillo, \\ Coahuila, México. \\ 'Email:ivonn1590@hotmail.com Tel:+52-1-6441190667 \\ Email:fdanielhc@hotmail.com Tel: +52-1-8444550996 \\ Email: green.ungsondiana@gmail.com Tel: +52-1-6682447367 \\ Ex, INIFAP, Campo Experimental Norman E. Borlaug Apdo., Valle del Taqui, Cd. Obregón, \\ Sonora, México. \\ Email:fuentes.davila@gmail.com Tel:+52-1-6441426207 \\ Email: j_luis_ff@yahoo.com.mx Tel: +52-1-6441620672 \\ ${ }^{5}$ Email:almaaoa75@hotmail.com Tel:+52-1-644139044.9 \\ ${ }^{6}$ Email: cortesijm@hotmail.com Tel: +52-1-6444472311
}

\section{ABSTRACT}

Chickpea (Cicer arietinum L.) production is constantly compromised by a complex of pathogens which cause wilt and root rot (WRR). Therefore, biological control and organic products have regained great importance in the last few years. In this work, polyphenols were obtained from ethanolic extracts through the ultrasound-microwave assisted technique from the plant species chinese privet leaves (Ligustrum lucidum) and moringa leaves (Moringa oleifera). A qualitative analysis through reverse phase high-performance liquid chromatography electrospray ionization mass spectrometry (RP-HPLC-ESI-MS) was conducted, so that their biological effectiveness under greenhouse conditions was determined by each group of polyphenols against Fusarium oxysporum f. sp. ciceris, Fusarium solani, and Macrophomina phaseolina which comprise the wilt and root rot complex. A complete randomized block design was established with three blocks and five treatments with nine replications each. Treatments were: Polyphenols of Ligustrum lucidum, polyphenols of Moringa oleifera, the fungicide Benomyl, the inoculated check, and the untreated check. The analysis of variance was performed and mean comparison with Duncan`s multiple range test (0.05). The results indicate that all groups of polyphenol had in their chemical composition, some compounds of known microbial activity, such as hydroxycinnamic acid, flavones, anthocyanins, catechins, and alkyphenols. Under greenhouse conditions, plants that had the lowest incidence and severity of the disease, were those treated with polyphenols from L. lucidum with $66 \%$ incidence, and were statistically different to the rest of the treatments.

Keywords: Chickpea, Cicer arietinum, Wilt, Root rot, Polyphenols, Biological control, Phytopathogens.

DOI: $10.20448 / 803.6 .1 .10 .21$

Citation | Ivón Alejandra ROSAS-JÁUREGUI; Guillermo FUENTES-DÁvILA; Francisco Daniel HERNÁNDEZ-CASTILLO; José Luis FÉLIX-FUENTES; Alma Angélica ORTIZ-AVALOS; Juan Manuel CORTÉS-JIMÉNEZ; Diana COTA-UNGSON (2021). Biological Effectiveness of Plant Polyphenols under Greenhouse Conditions, Against Wilt and Root Rot Complex of Chickpea (Cicer arietinum L.). Canadian Journal of Agriculture and Crops, 6(1): 10-21.

Copyright: This work is licensed under a Creative Commons Attribution 3.0 License

Funding: This study received no specific financial support.

Competing Interests: The authors declare that they have no competing interests.

History: Received: 26 October 2021/ Revised: 29 November 2021/ Accepted: 16 December 2021/ Published: 27 December 2021

Publisher: Online Science Publishing 


\section{Highlights of this paper}

- In this work, polyphenols were obtained from ethanolic extracts through the ultrasoundmicrowave assisted technique from the plant species chinese privet leaves (Ligustrum lucidum) and moringa leaves (Moringa oleifera).

- A complete randomized block design was established with three blocks and five treatments with nine replications each.

\section{INTRODUCTION}

The area grown with chickpea (Cicer arietinum L.) in Mexico during the year 2016 was 66,096 ha with a production of 116,076 t. The states of Sinaloa and Sonora in the northwestern part of the country, were the main national chickpea producers providing 45 and 30\%, respectively [1]. Vascular wilt caused by the fungus Fusarium oxysporum Schlechtend.:Fr. f. sp. ciceris (Padwick) Matuo and K. Sato, is one of the most important diseases that affect chickpea. This disease is highly destructive and occurs worldwide [2]. Annual yield losses may range from 10 to $90 \%$, but the disease could reach $100 \%$ [2] when the crop is exposed to adverse conditions, such as heat or drought stress during the reproductive stage and development of pods [3]; in Spain, it may range between 12 to $15 \%$ [4]. It is suggested that Fusarium vascular wilt includes a complex of phytopathogens similar to the wilt and root rot (WRR), that severily affects chickpea seed production. Several fungi have been reported as causal agents of the WRR on chickpea, such as Fusarium, Rhizoctonia, Macrophomina, and Sclerotium [5]. Some of the strategies used for disease management are the cultivation of resistant cultivars, crop rotation, solarization, destruction of plant debris, and use of seed-free of pathogens or treated with fungicides, although the results have been limited [6]. Control with synthetic chemicals is the method most widely used for management of diseases caused by Fusarium species; however, the use of biological products has become more important in the last few years [7]. Many investigations focus on studies about natural product formulations that have some type of biological activity against phytopathogens, with greater efficacy and and faster action. This has generated more efficient practices in a wider range of environmental conditions, pest species, and crop systems [8]. Therefore, the objective of this work was to evaluate the biological effectiveness of two groups of polyphenols obtained through ethanolic extracts, against fungi associated to wilt and root rot of chickpea under greenhouse conditions.

\section{MATERIALS AND METHODS}

Plant materials used for elaboration of polyphenols were obtained from leaves of Ligustrum lucidum W.T. Aiton and Moringa oleifera Lam., which were dehydrated by placing them on brown paper during two weeks at $28-30^{\circ} \mathrm{C}$ in the laboratory; then, they were ground up in a blender in a $150 \mu \mathrm{m}$ Tyler RO-TAP RX-29 sieve shaker. The amount of leaves was sufficient to make up $500 \mathrm{~g}$ of pulverized material for each plant species. Then, the products were placed in the ultrasonic microwave reaction system XO-SM100 (Nanjing ATPIO Instrumens Manufacture Co., Ltd Company), with the amount obtained from the relationship shown in Table 1, under the following conditions: Ultrasonic (VS): power radio 20, ultrasonic on relay 10, ultrasonic off relay 3, amplitude off relay 25 and set time 20. Microwave (MV): Power radio 800, display power 0 , set temp $70^{\circ} \mathrm{C}$, and holding time 5 . After the ultrasound-microwave process, samples were stored in an ultrafreezer at $-70^{\circ} \mathrm{C}$, then, a column chromatography was carried out following the methodology described by De Asmundis, et al. [9].

Table-1. Description of the relationship from the assisted extraction through ultrasound-microwave of two plant species.

\begin{tabular}{llll}
\hline Source & Ethanol & mL:1 g of sample & Relationship \\
\hline Ligustrum lucidum & $70 \%($ high $)$ & $16($ high $)$ & high x high \\
\hline Moringa oleifera & $70 \%($ high $)$ & $16($ high $)$ & high x high \\
\hline
\end{tabular}


The ethanolic fraction obtained was divided in glass containers and dried in an oven at $60^{\circ} \mathrm{C}$, without exposure to light during 24 to $48 \mathrm{~h}$. The polyphenols were recovered by scrapping them with a spatula: $2,150 \mathrm{mg}$ of $L$. lucidum and 2,400 $\mathrm{mg}$ of $M$. oleifera. Then, they were stored in amber jars in darkness at $15-23^{\circ} \mathrm{C}$. After 8 days, the polyphenols obtained were subjected to a high resolution qualitative analysis through reverse phase highperformance liquid chromatography electrospray ionization mass spectrometry (RP-HPLC-ESI-MS), according to the methodology of Ascacio-Valdés, et al. [10]. Treatments with polyphenols were prepared as follows: for $L$. lucidum $340 \mathrm{mg}$ of the extract were dissolved in $400 \mathrm{~mL}$ of ethanol and water (8:2 v/v), while for M. oleifera $430 \mathrm{mg}$ of the extract were dissolved with the same proportion of ethanol/water. The solutions were maintained during 24 $\mathrm{h}$ in a rotary shaker and then kept at $14^{\circ} \mathrm{C}$ until their use. The fungicide treatment consisted of one gram of Benomyl 50 WP (PROMYL) (methyl $N$-[1-(butylcarbamoyl)benzimidazol-2-yl $]$ carbamate) which was dissolved in $1 \mathrm{~L}$ of water.

Strains of phytopathogens used in the evaluation. The strains used were isolated from chickpea plants with symptoms of wilt and yellowing Figure 1, collected at the Norman E. Borlaug Experimental Station in the Yaqui Valley, Sonora, Mexico $\left(27^{\circ} 29.185^{\prime} \mathrm{N},-109^{\circ} 56.45^{\prime} \mathrm{W}\right)$. Small root pieces with disease symptoms were disinfected with a $3 \%$ sodium hypochlorite solution, rinsed with sterile distilled water, placed in Petri plates containing potatodextrose-agar (PDA) culture medium, and incubated at $28^{\circ} \mathrm{C}$ during three days. The isolation was performed by hyphal tip and the molecular identification through the polymerase chain reaction (PCR) and random amplification of polymorphic DNA, following the methodologies described by Babu, et al. [11]; Arif, et al. [12] and JiménezGasco, et al. [13]. Fungal isolates were grown in $50 \mathrm{~mL}$ tubes with PDA at $28 \pm 2{ }^{\circ} \mathrm{C}$, and once they covered most of the medium, sterile mineral oil was added in order to maintain the cultures in darkness until their use. They also were grown and maintained on PDA in sterile Petri plates in a refrigerator.

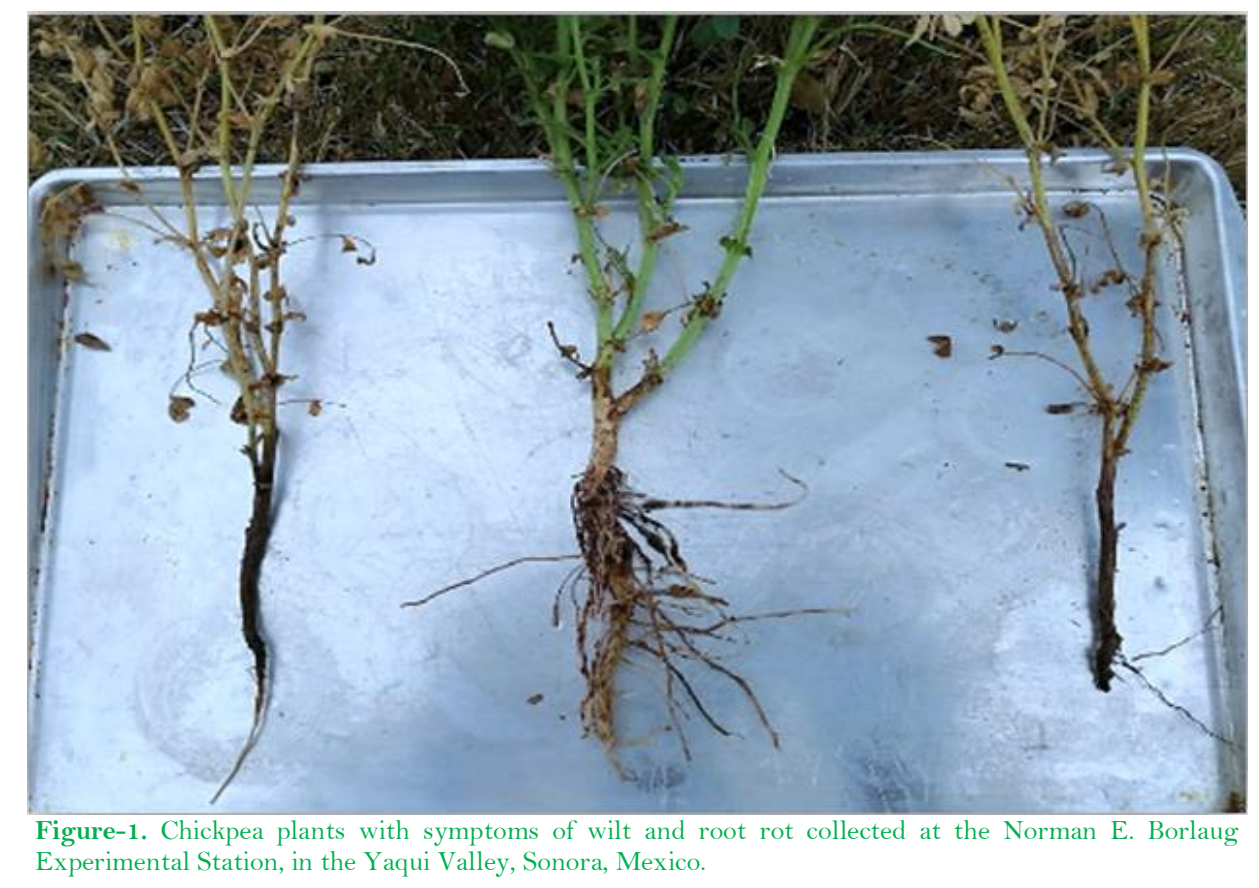

Greenhouse trial. The greenhouse trial was established during the fall-winter 2019-2020 at the Autonomous Agrarian University Antonio Narro, located at $25^{\circ} 37^{\prime} \mathrm{N}, 101^{\circ} 03^{\prime} 32^{*} \mathrm{~W}, 1,786$ masl, with subtropical and arid climate. Initially, four chickpea seeds per replication of cultivar Blanoro [14] were germinated in 1 L styrofoam cups with peat moss in the greenhouse at $18-29^{\circ} \mathrm{C}$. Polyphenols from treatments 1 and 2 were applied with Lion 
Tools ${ }^{\circledR} 2$ L sprayer just before transplanting; three sprays were applied to the orifice made for seedling placement. After 15 and 30 days, applications were directed to the base of the stem three times in each occasion. Benomyl was also applied in the same fashion already described for treatments 1 and 2. Seedlings from treatments 1 to 4 were inoculated before transplanting by making a $2 \mathrm{~cm}$ incision in the roots, then, they were placed in a micro and macroconidial suspension of F. oxysporum f. sp. ciceris and F. solani (Mart.) Sacc. at a concentration of $1 \times 10^{8}$ during 3 min. For the inoculation with Macrophomina phaseolina (Tassi) Goidanich, six sorghum grains previously inoculated in the laboratory following the methodology described by Pineda, et al. [15], were used for each seedling; they were placed close to the seedling roots. By the time of inoculations, fungal isolates had been stored in PDA-mineral oil and in Petri dishes with PDA for 6 months. After 25 days of emergence and seedlings were $10 \mathrm{~cm}$ tall, they were transplanted to black plastic bags No. 4 (volume $6 \mathrm{~L}$ ) with $4 \mathrm{~kg}$ of substrate, which was $60 \%$ soil and $40 \%$ coconut fiber. The substrate was previously pasteurized at $80^{\circ} \mathrm{C}$ during $10 \mathrm{~min}$, repeating the process three times. A total of 45 seedlings were used for the different treatments; therefore, a single seedling represented a replication. A complete randomized block design was established with three blocks and five treatments (T1: polyphenols of Ligustrum lucidum, T2: polyphenols of Moringa oleifera, T3: benomyl, T4: inoculated check, and T5: untreated check) Table 2, with fifteen replications in each block. The analysis of variance was carried out and the mean comparison with Duncan`s multiple range test (0.05). Disease incidence and severity were evaluated following the scale proposed by Carrillo [16] Table 3, and for root severity the scale proposed by Camargo [17] Table 4.

Table-2. Evaluation of several treatments to determine the antifungal effect on wilt and root rot complex of chickpea, under greenhouse conditions.

\begin{tabular}{ll}
\hline Treatments & Concentration $(\mathbf{m g})^{\mathbf{y}}$ \\
\hline T1 Polyphenol of Ligustrum lucidum & 340 \\
T2 Polyphenol of Moringa oleifera & 430 \\
T3 Fungicide Benomyl & $1 \mathrm{~g} \mathrm{c.p./L} \mathrm{water}{ }^{\mathrm{z}}$ \\
T4 Inoculated check & - \\
T5 Untreated check & - \\
\hline $\begin{array}{l}\text { Note: } \\
\text { yIn } 400 \mathrm{~mL} \text { of ethanol/water 8:2 v/v. }\end{array}$ & \\
${ }^{2}$ C.p. $=$ commercial product.
\end{tabular}

Table-3. Rating scales for disease incidence and severity of wilt and root rot complex in chickpea.

\begin{tabular}{llll}
\hline & Rating & Description & Evaluation (\%) \\
\hline Incidence & $0-100$ & Percentage of affected plants & $0-100$ \\
Severity & 0 & Healthy plant & 0 \\
& 1 & Chlorotic plant & 25 \\
& 2 & Withered plant & 50 \\
& 3 & Infected plant and symptoms on foliage & 75 \\
\hline 4 & Dead plant & 100 \\
\hline
\end{tabular}

Table-4. Rating scale for severity on roots caused by the wilt and root rot complex of chickpea.

\begin{tabular}{lll}
\hline Rating scale & Description & Root system damaged (\%) \\
\hline 0 & Healthy roots & 0 \\
1 & Root system damaged & $1-10$ \\
2 & “ & $11-15$ \\
3 & “ & $16-30$ \\
4 & Complete necrosis of the root system & $31-50$ \\
5 & & $51-75$ \\
\hline
\end{tabular}

\section{RESULTS AND DISCUSSION}

Different phytochemicals were identified through liquid chromatography (HPLC-MS) Table 5. The extract from Moringa oleifera showed flavones, anthocyanins, hydroxycinnamic acids, and curcuminoids; in the case of the 
extract of Ligustrum lucidum flavones, alkyphenols, and hydroxycinnamic acids. The results obtained coincide with those mentioned by Saravanakumar, et al. [18], who reported that the phenolyc type compounds such as coumarins, lignins, flavonoids, and tannins are present in the defense plant system via tissue or cell wall modification, providing hardiness or rigidity. Based on the identification of polyphenols from L. lucidum, it is considered that they have antifungal activity by the results obtained, as well as those from M. oleifera. It is known that phenolic compounds have protective functions against pathogenic microorganisms [19], and that they are necessary for plant survival under stress conditions imposed by biotic and abiotic factors [20]. There are reports about the use of phenolic compounds as inhibitors of diverse pathogens, like Mendoza, et al. [21] who reported the potential of these compounds against Botrytis cinerea Pers. ex Fr. Therefore, the diminish of the disease observed in our study with polyphenos by the diverse treatments applied, could have been due to the presence of metabolites, such as flavonoids which have a wide range of biological activity [22]. There have been quite a number of investigations about the efficacy of plant metabolites affecting fungal growth and development. [23] found that flavonoids of Sophora flavescens Aiton at concentrations of 0.25, 0.5, 1, 2, and $4 \mathrm{~g} / \mathrm{L}$ restrained the mycelial growth of Fusarium oxysporum Schlechtend.:Fr. f. sp. cucumerinum J.H. Owen, and stimulative rates were enhanced with the increased concentration.

Table-5. Groups of polyphenols detected from plant extracts through high-performance liquid chromatography mass spectrometry.

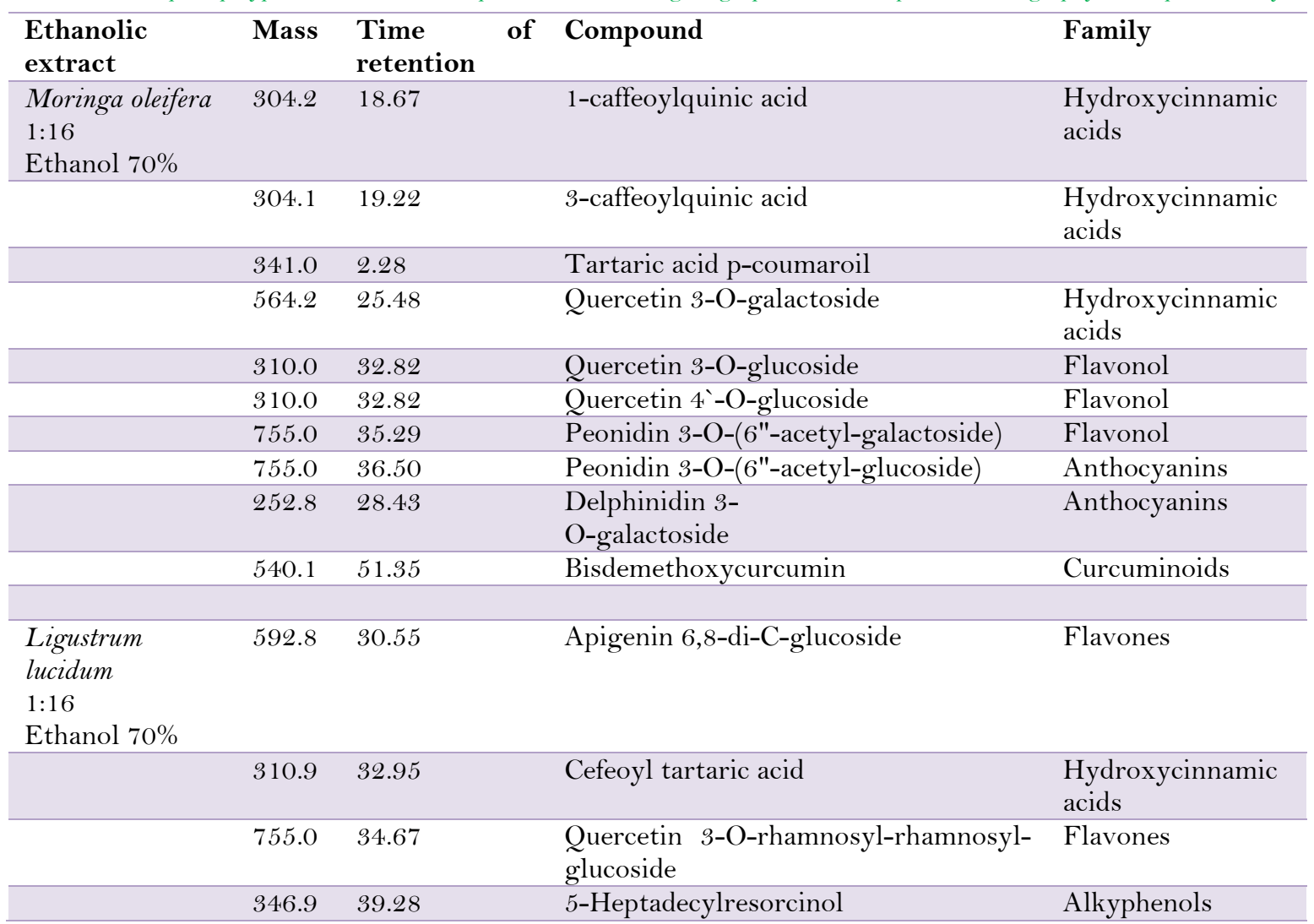

With a $4 \mathrm{~g} / \mathrm{L}$ concentration of flavonoids, the inhibition rate was $93.08 \%$. In the therapeutic trail, plants have the biggest promotion by $60 \mathrm{~g} / \mathrm{L}$ of flavonoids; the results indicated that chlorophyll content, root activity, superoxide dismutase (SOD) activity, peroxidase (POD) activity and phenylalanine ammonia-lyase (PAL) activity were increased by $17.79 \%, 71.55 \%, 48.20 \%, 123.80 \%$, and $151.48 \%$, respectively, in comparison with the control. The results of the prevention trail indicated that flavonoids of Sophora flavescens enhanced disease resistance of 
cucumber at all the concentrations, and the best effect occurred with $80 \mathrm{~g} / \mathrm{L}$. Plant extracts and essential oils of each plant might have more than sixty compounds, and some of them could have antifungal properties. Generally, they are present in mixtures, and pathogens might be affected differentially, and by individual or mixtures at certain concentrations and proportions Montes-Belmont [24]. Tenorio, et al. [25] reported that the biocontrol activity of extracts from Caiphora andina Urb. and Gilg and a saponin isolated from the skin of Chenopodium quinoa Wild., caused an inhibition of $35 \%$ and $36 \%$, respectively, on the fungus Ulocladium spp. Ch. quinoa showed an inhibition of 42\% on Aspergillus flavus Link: Fr. Wang, et al. [26] indicated that the methanol extract of Ficus sarmentosa var. henryi (King) Corner has potent inhibitory activities against Fusarium graminearum Schwabe, Curvularia lunata (Wakker) Boed, Septoria zeicola Sout, Botrytis cinerea Pers.:Fr., and Rhizoctonia solani Kühn. Four flavonoids were isolated from this plant: eriodictyol, homoeriodictyol, dihydroquercetin, and luteolin. Contreras-Arredondo, et al. [27] found hydrolyzable and condensed tannins as active ingredients against Fusarium oxysporum in potato (Solanum tuberosum L.), which were obtained from ethanolic extracts of antelope bush flower (Cowania plicata D. Don.); the results indicated that the lowest inhibitory concentration 50 was 3,000 ppm, and the highest 90 was 28,000 ppm on the fungus. Murillo-Arango, et al. [28] reported that citronelal and geraniol essential oil from Eucalyptus tereticornis Smith had a funcididal effect on Fusarium oxysporum at $3 \mathrm{~g} / \mathrm{L}$ concentration and a fungicidal activity at small concentrations. Two extracts obtained from Acacia farnesiana (L.) Willd., one hydroalcoholic and the other one aqueous, were evaluated on the fungus Fusarium oxysporum f. sp. lycopersici (Sacc.) Snyder and Hansen, in terms of percentage of mycelial growth inhibition and a qualitative chemical analysis was performed; both extracts showed more than 90\% mycelial growth inhibition in the first evaluation (72 hours) after the inoculation. Both extracts showed the presence of metabolites which are known to have antimicrobial activity, such as flavonoids, tannins, phenols, alkaloids, and saponins [29]. Extracts from Amaranthus spinosus L. caused lysis of Phakopsora pachyrhizi Sydow and Sydow; this plant species contains alkaloids, flavonoids, tannins, saponins, and terpenoids which can be used as botanical fungicide to inhibit spore germination Yusnawan [30]. Guerrero, et al. [31] reported that extracts from Amaranthus viridis L., Cyperus odoratus L., Euphorbia hirta L., Tagetes minuta L., Scoparia dulcis L., and Portulaca oleracea L. affected somewhat the development of Theobroma cacao L. pathogens: Moniliophthora roreri (Cif.) H.C. Evans, Stalpers, Samson and Benny, and Phytophthora palmivora (Butl.) Butl. in vitro on all the variables studied; however, the effect of $A$. viridis and $E$. hirta was noticeably superior to the other species.

Seedlings with the lowest incidence of wilt and root rot were those treated with polyphenols from L. lucidum which had $66.66 \%$ Figure 2. The analysis of variance showed significant differences between polyphenols from $L$. lucidum and the rest of the treatments. The coefficient of variation was $19.1 \%$. Incidence of WRR in seedlings treated with polyphenols from $M$. oleifera had $88.88 \%$, and were statistically similar to the synthetic chemical check and the inoculated check. These two last treatments had a disease incidence of $100 \%$, while in the untreated check no presence of the disease was detected. Disease severity in seedlings treated with polyphenols obtained from $L$. lucidum showed a range of 0.0 to 4.0 with an average of 1.44 , while those from M. oleifera had a range of 0.0 to 4.0 with an average of 2.33 , being statistically greater and different from the severity shown with the benomyl treatment which was not able to provide any control the disease Figure 3. Benomyl and the inoculated check had a disease incidence value of 5.0, while the untreated check had 0. The coefficient of variation was $11.1 \%$. Significant differences were detected between treatments in root rot severity Figure 4; polyphenols obtained from L. lucidum showed the lowest severity with a range of 0.8 to 1.4 with an average of 1.1 , polyphenols obtained from M. oleifera had a range of 1.6 to 2.2 with an average of 1.86 , the benomyl treatment had a range of 3.7 to 5.0, in comparison with the inoculated check which showed a severity value of 5.0. 


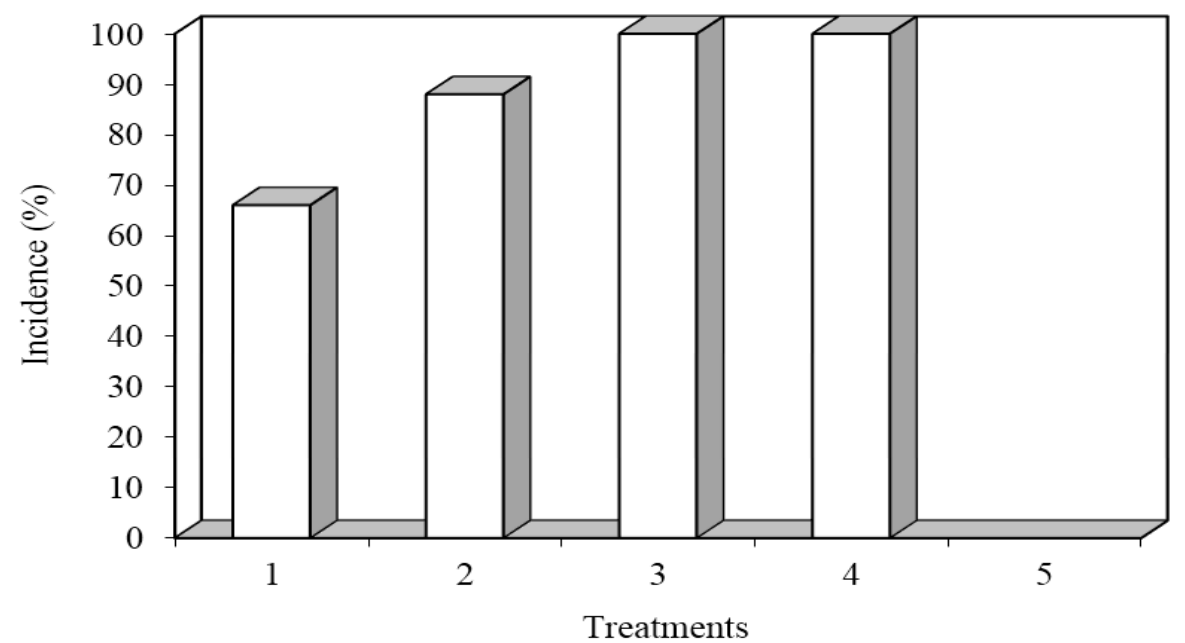

Figure-2. Incidence of wilt and root rot of chickpea seedlings inoculated under greenhouse conditions. Treatments: $1=$ Ligustrum lucidum, $2=$ Moringa oleifera, $3=$ Benomyl, $4=$ Inoculated check, $5=$ Untreated check.

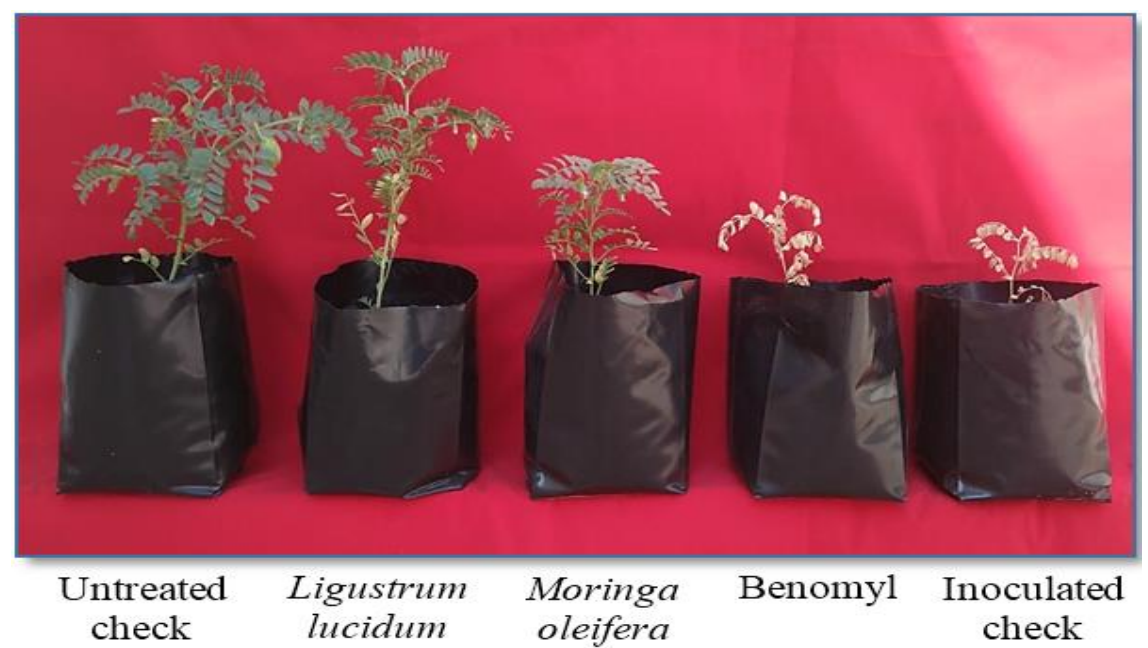

Figure-3. Disease severity in chickpea seedings inoculated with Fusarium oxysporum f. sp. ciceris, Fusarium solani, and Macrophomina phaseolina, causal agents of wilt and root rot, after treatment with plant polyphenols.

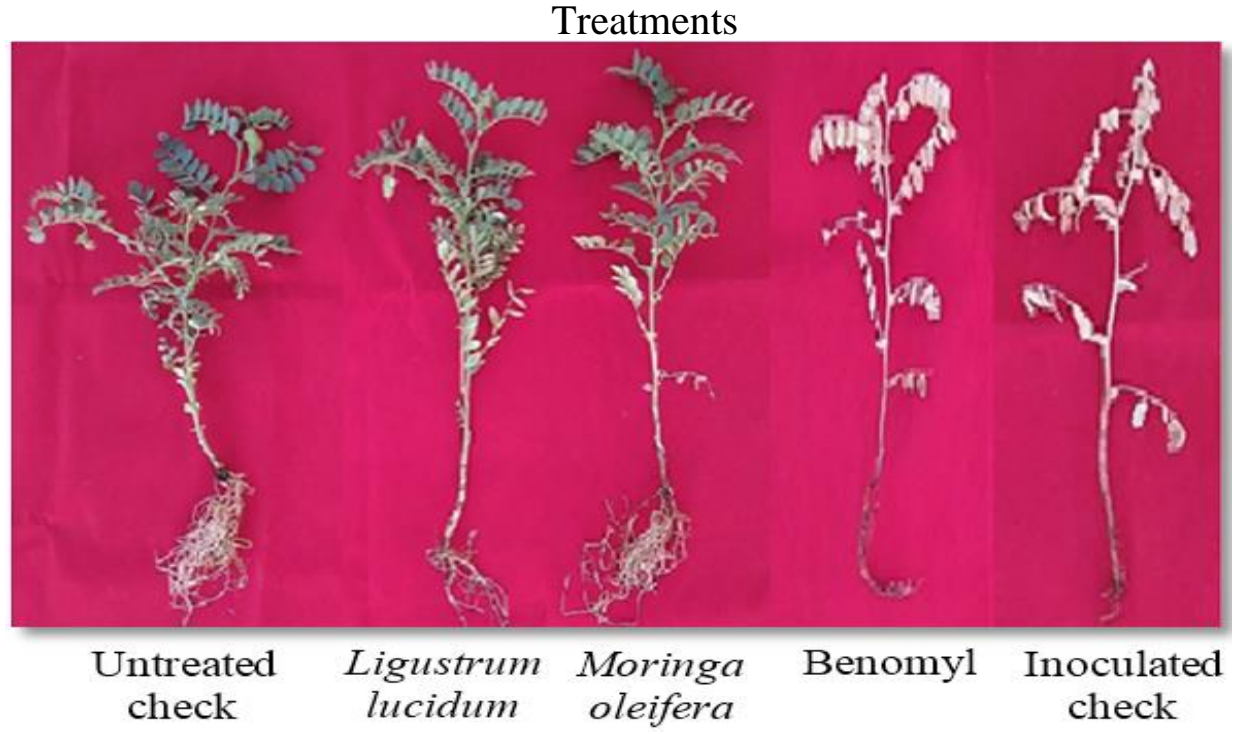

Figure-4. Disease severity in chickpea roots inoculated with Fusarium oxysporum f. sp. ciceris, Fusarium solani, and Macrophomina phaseolina, causal agents of wilt and root rot, after treatment with plant polyphenols, under greenhouse conditions. 
In this study, development of the disease was high based on the severity values shown by the inoculated check and the untreated check, which had a range of 0.0 to 0.9 with an average of 0.24 . The tolerance and resistance to benomyl by other phytopathogenic fungi has been reported previously, like Botrytis cinerea whose resistance was first reported in Holland in 1970 in isolates of ciclamen (Cyclamen sp. L.), after the product had been used for two years. Later, it was detected in isolates from rose (Rosa sp. L.) in Canada, then in Pennsylvania, USA on rose, geranium (Pelargonium X hortorum L.H. Bailey), begonia (Begonia X tuberhybrida Voss), petunia (Petunia sp. Juss.), cyclamen, and fuchsia (Fuchsia hybrida Voss) Bollen and Scholten [32]; Watson and Koons [33]; Miller and Fletcher [34]; Jarvis and Slingsby [35]; Bolton [36]; Moorman and Lease [37]. Coley-Smith [38] reported that the development of resistance to fungicides by B. cinerea is very important in the control of diseases that this fungus causes, primarily when benzimidazols have been used. Fungicides have been used for about two hundred years to protect plants from fungal diseases [39]. Despite the progress of chemical control against fungal diseases, the phenomenon of resistance by phytopathogens to the phytosanitary products constitutes a problem that worries the sector from the agronomic point of view. Systemic fungicides is a group of chemicals that have frequently presented such a problem; numerous cases of pathogen resistance in the field have been reported, which provoques a maladjustment in the population equilibrium from the ecological point of view. In many European, Asian, and Latinoamerican countries where this type of fungicides are used regularly, research studies are carried out with the objective to detect on time, the possible appearance of resistance in order to avoid production losses in crops of economic importance. The first research related to this topic in Cuba, was carried out when resistance to benomyl was detected in Mycosphaerella musicola J.L. Mulder in J.L. Mulder and Stover on banana [40]. The objective was to reduce the fungus population in order to minimize the development of resistance and to reduce the number of chemical applications. The solutions developed in Cuba since the 80'refer to the implementation of integrated management programs, which include genetic methods, biological, and cultural, combined with the application of fungicides, so that they offer a satisfactory option to reduce the selection pressure towards resistance, as a contribution to the development of sustainable agriculture. Manzo Sánchez, et al. [41] reported that according to sensitive analysis towards fungicides, ten isolates of Mycosphaerella fijiensis Morelet, causal agent of black sigatoka in banana, presented loss of sensitivity to benomyl, seven to propiconazol, and nine to azoxystrobin. The isolates were able to grow to concentrations that indicate the loss of sensitivity. Regarding the fungus Venturia inaequalis (Cook) Wint., the causal agent of apple scab, the preventive and curative activity of benzimidazols allows the scheduled application of benomyl, at 10 to 14 day intervals; this frequency has caused the appearance of resistant isolates of this fungus to the fungicide after three to four years of use in other places [42]. Research carried out in the United States, Germany, France, and Israel show that the resistance of $V$. inaequalis to benomyl is due the mutation of a single mendelian gene, and that the levels of resistance may vary depending upon the isolates [43-46]. In Mexico, the evaluation of fungicides for control of $V$. inaequalis in the Lirios region of Arteaga county in the state of Coahuila, provides evidence of inadequate protection when benzimidazol products are used, since it was observed a $26 \%$ incidence of damaged fruits, and that protective fungicides like mancozeb and captan only recorded $8 \%$ of fruits damaged [47]. For the treatment of diseases caused by Fusarium spp. and other fungi, systemic fungicides like benzimidazols are used, which include benomyl, carbendazim, thiabendazol, and thiophanate; however, it is probable that these fungicides also act as mutagenic agents in plants, and they might cause an increment in the level of resistance of pathogens Agrios [48]. Dane and Dalgiç [49] demonstrated the genotoxic effect of benomyl in onion roots (Allium cеpa L.) when treated with different rates of this fungicide; anomalies were observed in the interphase and mitotic divisions of meristematic cells. These anomalies were due to the deffect of the mitotic spindle and karyokinesis without cytokinesis. Negative effects were also observed on the chromatic such as condensation and 
noncondensation, and some abnormal vacuoles in the interphase. Other fungi have been studied to elucidate at the molecular level, the genes or mutations that trigger the resistance to benzimidazol compounds [50-58].

\section{CONCLUSIONS}

Different phytochemicals obtained from Moringa oleifera and Ligustrum lucidum were identified through liquid chromatography (HPLC-MS). The extract from M. oleifera showed flavones, anthocyanins, hydroxycinnamic acids, and curcuminoids; in the case of the extract from L. lucidum flavones, alkyphenols, and hydroxycinnamic acids. Polyphenols from these plant species reduced the incidence and severity of the Fusarium wilt and root rot of chickpea, and enhanced better plant development. The results obtained with polyphenos from L. lucidum are the first reported for control of a plant disease.

\section{REFERENCES}

[1] SIAP (Agri-Food and Fishery Information System), "Advance of sowings and harvests, national summary by crop. Retrieved from: https://www.gob.mx/siap/. [Accessed November 22, 2020]," 2020.

[2] K. D. Sharma and F. J. Muehlbauer, "Fusarium wilt of chickpea: Physiological specialization, genetics of resistance and resistance gene tagging," Euphytica, vol. 157, pp. 1-14, 2007.

[3] B. B. Landa, J. A. Navas-Cortés, M. del Mar Jimenez-Gasco, J. Katan, B. Retig, and R. M. Jiménez-Díaz, "Temperature response of chickpea cultivars to races of Fusarium oxysporum f. sp. ciceris, causal agent of Fusarium wilt," Plant Disease, vol. 90, pp. 365-374, 2006.

[4] A. Trapero Casas and R. M. Jiménez Díaz, "Fungal wilt and root rot diseases of chickpea in southern Spain," Phytopathology, vol. 75, pp. 1146-1151, 1985.

[5] I. Padilla-Valenzuela, R. I. Valenzuela-Valenzuela, C. M. Armenta-Castro, R. A. Salinas-Pérez, and E. SánchezSánchez, "Agronomic behavior of chickpea genotypes in late sowing in the Mayo Valley, Sonora, Mexico," Mexican Phytotechnics Magazine, vol. 31, pp. 43-43, 2008.

[6] J. E. Paredes-Escalante, J. A. Carrillo-Fasio, R. S. García-Estrada, R. Allende-Molar, J. A. Sañudo-Barajas, and J. B. Valdez-Torres, "Antagonist microorganisms for the control of the fungal complex that causes rabies in chickpea (Cicer arietinum L.) in the State of Sinaloa, Mexico," Mexican Journal of Phytopathology, vol. 27, pp. 27-35, 2009.

[7] M. Basco, K. Bisen, C. Keswani, and H. Singh, "Biological management of Fusarium wilt of tomato using biofortified vermicompost," Mycosphere, vol. 8, pp. 467-483, 2017.

[8] D. Gakuya, S. Itonga, J. Mbaria, J. Muthee, and J. Musau, "Ethnobotanical survey of biopesticides and other medicinal plants traditionally used in Meru central district of Kenya," Journal of Ethnopharmacology, vol. 145, pp. 547-553, 2013.

[9] C. De Asmundis, C. H. Romero, H. A. Acevedo, R. G. Pellerano, and F. A. Vázquez, "Functionalization of an ion exchange resin for the preconcentration of HG (II)," Advances in Science and Engineering, vol. 2, pp. 63-70, 2011.

[10] J. A. Ascacio-Valdés, A. F. Aguilera-Carbó, J. J. Buenrostro, A. Prado-Barragán, R. Rodríguez-Herrera, and C. N. Aguilar, "The complete biodegradation pathway of ellagitannins by Aspergillus niger in solid-state fermentation," Journal of Basic Microbiology, vol. 56, pp. 329-336, 2016.Available at: https://doi.org/10.1002/jobm.201500557.

[11] B. K. Babu, A. K. Saxena, A. K. Srivastava, and D. K. Arora, "Identification and detection of Macrophomina phaseolina by using species-specific oligonucleotide primers and probe," Mycologia, vol. 99, pp. 797-803, 2007.

[12] M. Arif, S. Chawla, M. Zaidi, J. Rayar, M. Variar, and U. Singh, "Development of specific primers for genus Fusarium and F. solani using rDNA sub-unit and transcription elongation factor (TEF-1 $\alpha$ ) gene," African Journal of Biotechnology, vol. 11, pp. 444-447, 2012.Available at: https://doi.org/10.5897/ajb10.489. 
[13] d. M. M. Jiménez-Gasco, E. Pérez-Artés, and R. M. Jiménez-Diaz, "Identification of pathogenic races 0, 1B/C, 5, and 6 of Fusarium oxysporum f. sp. ciceris with random amplified polymorphic DNA (RAPD)," European Journal of Plant Pathology, vol. 107, pp. 237-248, 2001.

[14] P. F. Ortega Murrieta, G. A. Fierros Leyva, I. Padilla Valenzuela, V. Valenzuela Herrera, J. A. Acosta-Gallegos, E. Gutiérres Perez, S. Velarde Félix, and F. G. Rodríguez Cota, "Blanoro, new white chickpea variety with extra-large grain for exportation," Mexican Journal of Agricultural Sciences, vol. 7, pp. 209-2 16, 2016.

[15] J. Pineda, A. Hernández, A. González, V. Barrientos, H. Nass, and E. Gil, "Fast and efficient inoculation technique for the evaluation of maize (Zea mays L.) materials against Rhizoctonia solani Kuhn," Bioagro, vol. 17, pp. 93-98, 2005.

[16] F. A. Carrillo, Biological alternative for the control of root diseases (Fusarium oxysporum f. Sp. Ciceris, Sclerotium rolfsii and Rhizoctonia solani) of chickpea (Cicer arietinum L.) in the State of Sinaloa, Mexico. Sinaloa, Mexico: Memory of Regional Chickpea Forum. Guamúchil, 2004.

[17] T. Camargo, "Chemical control of the wart (Synchytrium endobioticum), and rhizoctoniasis (Rhizoctonia solani) of the potato, through the use of new fungicides," Doctoral Dissertation, Graduate Thesis. Technical University of OruroUTO. Oruro, Bolivia, 1999.

[18] D. Saravanakumar, L. Karthiba, R. Ramjegathesh, K. Prabakar, and T. Raguchander, Characterization of bioactive compounds from botanicals for the management of plant diseases. Sustainable Crop Disease Management Using Natural Products. Wallingford, UK: Center for Agriculture and Bioscience International (CABI), 2015.

[19] E. Osorio, M. Flores, D. Hernández, J. Ventura, R. Rodríguez, and C. N. Aguilar, "Biological efficiency of polyphenolic extracts from pecan nuts shell (Carya Illinoensis), pomegranate husk (Punica granatum) and creosote bush leaves (Larrea tridentata Cov.) against plant pathogenic fungi," Industrial Crops and Products, vol. 31, pp. 153-157, 2010.Available at: https://doi.org/10.1016/j.indcrop.2009.09.017.

[20] N. C. Do Nascimento and A. G. Fett-Neto, "Plant secondary metabolism and challenges in modifying its operation: An overview," Plant Secondary Metabolism Engineering, vol. 643, pp. 1-13, 2010.

[21] L. Mendoza, K. Yánez, M. Vivanco, R. Melo, and M. Cotoras, "Characterization of extracts from winery by-products with antifungal activity against Botrytis cinerea," Industrial Crops and Products, vol. 43, pp. 360-364, 2016.

[22] G. M. C. Lizcano, "Evaluation of the fungicidal activity of thyme extract (Thymus vulgaris) against Botrytis cinerea, Fusarium oxysporum and Sclerotinia sclerotiorum", Agricultural and Veterinary Microbiology," Thesis. Pontificia Universidad Javeriana, Bogotá, Colombia, 2007.

[23] B. L. Zhou, T. Yao, J. Zhang, and X. L. Ye, "Effects of flavonoids of Sophora flavescens to Fusarium Wilt and resistance physiology of cucumber," Acta Agriculturae Boreali-Sinica, vol. 24, pp. 78-82, 2009.

[24] R. Montes-Belmont, "Diversity of chemical compounds produced by plants against phytopathogenic fungi," Mexican Journal of Mycology, vol. 29, pp. 73-82, 2009.

[25] R. Tenorio, E. Terrazas, M. T. Alvarez, J. L. Vila, and P. Mollinedo, "Chenopodium quinoa and Caiphora andina saponin concentrates: alternatives as biocontrollers of phytopathogenic fungi," Bolivian Journal of Chemistry, vol. 27, pp. 33-40, 2010.

[26] X.-G. Wang, X.-Y. Wei, Y.-Q. Tian, L.-T. Shen, and H.-H. Xu, "Antifungal flavonoids from Ficus sarmentosa var. henryi (King) Corner," Agricultural Sciences in China, vol. 9, pp. 690-694, 2010.Available at: https://doi.org/10.1016/s1671-2927(09)60144-9.

[27] M. E. Contreras-Arredondo, F. F. Hernández-Castillo, A. Sánchez-Arizpe, G. Gallegos-Morales, and d. R. D. Jasso, "Fungicidal activity of Cowania plicata D. Don extracts. against Fusarium oxysporum Schlechtend. Fr. and of Pistacia lentiscus L. against Colletotrichum coccodes Wallr. Hunghes," Agrarian Magazine Nueva Epoca, vol. 8, pp. 6-13, 2011. 
[28] W. Murillo-Arango, J. M. Acevedo-Ruíz, and C. A. Peláez- Jaramillo, "Fungicidal activity of Eucalyptus tereticornis essential oil on the pathogenic fungus Fusarium oxysporum," Cuban Journal of Pharmacy, vol. 45, pp. 264-274, 2011.

[29] P. A. T. Rodríguez, M. A. R. Arrebato, S. B. Baños, A. C. Triana, and D. R. González, "Antifungal activity of Acacia farnesiana extracts on the in vitro growth of Fusarium oxysporum f. sp. lycopersici," UDO Agricultural Scientific Journal, vol. 12, pp. 91-96, 2012.

[30] E. Yusnawan, "Inhibition of spore germination of Phakopsora pachyrhizi using crude extracts of Amaranthus spinosus," Procedia Food Science, vol. 3, pp. 340-347, 2015.Available at: https://doi.org/10.1016/j.profoo.2015.01.037.

[31] R. Guerrero, G. Risco, O. Cevallos, R. Villamar, and S. Peñaherrera, "Plant extracts: An alternative for disease control in cocoa cultivation (Theobroma cacao)," Engineering and Innovation, vol. 8, 2021.Available at: https://doi.org/10.21897/23460466.2326.

[32] G. Bollen and G. Scholten, "Acquired resistance to benomyl and some other systemic fungicides in a strain of Botrytis cinerea in cyclamen," Netherlands Journal of Plant Pathology, vol. 77, pp. 83-90, 1971.Available at: https://doi.org/10.1007/bfo1981496.

[33] A. G. Watson and C. E. Koons, "Increased tolerance to benomyl in greenhouse populations of Botrytis cinerea," Phytopathology, vol. 63, pp. 1218-1219, 1973.

[34] M. Miller and J. Fletcher, "Benomyl tolerance in Botrytis cinerea isolates from glasshouse crops," Transactions of the British Mycological Society, vol. 62, pp. 99-103, 1974.Available at: https://doi.org/10.1016/s0007-1536(74)80010-0.

[35] W. Jarvis and K. Slingsby, "Tolerance of Botrytis cinerea and rose powdery mildew to benomyl," Canadian Plant Disease Survey, vol. 55, p. 44, 1975.

[36] A. Bolton, "Fungicide resistance in Botrytis cinerea, the result of selective pressure on resistant strains already present in nature," Canadian Journal of Plant Science, vol. 56, pp. 861-864, 1976.Available at: https://doi.org/10.4141/cjps76139.

[37] G. W. Moorman and R. Lease, "Benzimidazole-and dicarboximide-resistant Botrytis cinerea from Pennsylvania greenhouses," Plant Disease, vol. 76, pp. 477-480, 1992.

[38] J. R. Coley-Smith, The biology of botrytis. New York. USA: Academic Press, 1980.

[39] K. J. Brent and D. W. Hollomon, "Fungicide resistance in crop pathogens: How can it be managed?," 2nd ed Belgium: Croplife Intenational, Brussels, 2007, p. 56

[40] L. Pérez, M. Iglesias, and F. Mauri, "Appearance of a race, resistant to benomyl, of Mycosphaerella musicola, causal agent of Sigatoka in plantain," Agrotecnia De Cuba, vol. 17, pp. 79-88, 1985.

[41] G. Manzo Sánchez, H. Carrillo Madrigal, S. Guzmán González, and M. Orozco Santos, "In vitro sensitivity analysis of mycosphaerella fijiensis, causal agent of Banana Black Sigatoka to the Fungicides Benomyl, Propiconazole and Azoxystrobin," Mexican Journal of Phytopathology, vol. 30, pp. 81-85, 2012.

[42] H. Novacka, W. Karolczak, and D. F. Millikan, "Tolerance of the apple scab fungus to the benzimidazole fungicides in Poland," Plant Disease Reporter, vol. 61, pp. 346-350, 1977.

[43] V. Stanis and A. Jones, "Genetics of benomyl resistance in Venturia inaequalis from North and South America, Europe, and New Zealand," Canadian Journal of Plant Pathology, vol. 6, pp. 283-290, 1984.Available at: https://doi.org/10.1080/07060668409501530.

[44] J. Kiebacher and G. Hoffmann, "Genetics of benzimidazole resistance in Venturia inaequalis," Journal of Plant Diseases and Protection, vol. 88, pp. 189-205, 1981.

[45] D. Martin, J.-M. Olivier, and Y. Lespinasse, "Obtaining in vitro perithecia of Venturia inaequalis (Cke.) Wint; Application to the analysis of resistance to benomyl acquired in orchards," Agronomy, vol. 1, pp. 745-750, 1981. 
[46] T. Katan, E. Shabi, and D. Gilpatrick, "Genetics of resistance to benomyl in Venturia inaequalis isolates from Israel and New York," Phytopathology, vol. 73, pp. 600-603, 1983.

[47] B. Becerra-Verdin, "Evaluation of fungicides for the control of apple scab Venturia inaequalis (Cke.) Wint. in the Rancho Nuevo ejido, Municipality of Arteaga, Coahuila," Bachelor's Thesis, Antonio Narro Autonomous Agrarian University. Buenavista, Saltillo, Coahuila, Mexico, 1992.

[48] G. Agrios, Plant pathology, 5th ed. New York, USA: Elsevier Academic Press, 2005.

[49] F. Dane and Ö. Dalgiç, "The effects of fungicide benomyl (benlate) on growth and mitosis in onion (Allium cepa L.) root apical meristem," Acta Biologica Hungarica, vol. 56, pp. 119-128, 2005.Available at: https://doi.org/10.1556/abiol.56.2005.1-2.12.

[50] R. N. Cooley and C. E. Caten, "Molecular analysis of the Septoria nodorum $\beta$-tubulin gene and characterization of a benomyl-resistance mutation," Molecular and General Genetics MGG, vol. 237, pp. 58-64, 1993.Available at: https://doi.org/10.1007/bfoo282784.

[51] J. H. Pereira and N. Martinez-Rossi, "At least three genes are responsible for benomyl-resistance in Metarhizium anisopliae," The New Microbiologica, vol. 17, pp. 45-50, 1994.

[52] M. R. Bogo, M. H. Vainstein, F. J. Aragão, E. Rech, and A. Schrank, "High frequency gene conversion among benomyl resistant transformants in the entomopathogenic fungus Metarhizium anisopliae," FEMS Microbiology Letters, vol. 142, pp. 123-127, 1996.Available at: https://doi.org/10.1111/j.1574-6968.1996.tbo8418.x.

[53] S.-Y. Park, O.-J. Jung, Y.-R. Chung, and C.-W. Lee, "Isolation and characterization of a benomyl-resistant form of beta-tubulin-encoding gene from the phytopathogenic fungus Botryotinia fuckeliana," Molecules \& Cells (Springer Science \& Business Media BV), vol. 7, pp. 104-109, 1997.

[54] Z. Ma, M. A. Yoshimura, B. A. Holtz, and T. J. Michailides, "Characterization and PCR-based detection of benzimidazole-resistant isolates of Monilinia laxa in California," Pest Management Science: formerly Pesticide Science, vol. 61, pp. 449-457, 2005.Available at: https://doi.org/10.1002/ps.982.

[55] Z. Ma, M. A. Yoshimura, and T. J. Michailides, "Identification and characterization of benzimidazole resistance in Monilinia fructicola from stone fruit orchards in California," Applied and Environmental Microbiology, vol. 69, pp. 71457152, 2003.

[56] Y. Luo, Z. Ma, and T. J. Michailides, "Quantification of allele E198A in beta-tubulin conferring benzimidazole resistance in Monilinia fructicola using real-time PCR," Pest Management Science: Formerly Pesticide Science, vol. 63, pp. 1178-1 184, 2007.Available at: https://doi.org/10.1002/ps.1425.

[57] R. Nakaune and M. Nakano, "Benomyl resistance of Colletotrichum acutatum is caused by enhanced expression of $\beta$ tubulin 1 gene regulated by putative leucine zipper protein CaBEN1," Fungal Genetics and Biology, vol. 44, pp. 13241335, 2007.Available at: https://doi.org/10.1016/j.fgb.2007.03.007.

[58] C. Wen-Hsin, C. Wen-Chuan, P. Mun-Tsu, Y. Hong-Ren, and H. Jenn-Wen, "Specific detection of benzimidazole resistance in Colletotrichum gloeosporioides from fruit crops by PCR-RFLP," New Biotechnology, vol. 27, pp. 17-24, 2010.

Online Science Publishing is not responsible or answerable for any loss, damage or liability, etc. caused in relation to/arising out of the use of the content. Any queries should be directed to the corresponding author of the article. 